Tropical Journal of Pharmaceutical Research February 2017; 16 (2): 387-396

ISSN: $1596-5996$ (print); 1596-9827 (electronic)

(C) Pharmacotherapy Group, Faculty of Pharmacy, University of Benin, Benin City, 300001 Nigeria.

All rights reserved.

Available online at http://www.tjpr.org

Original Research Article

http://dx.doi.org/10.4314/tjpr.v16i2.18

\title{
Community of endophytic fungi from the medicinal and edible plant Fagopyrum tataricum and their antimicrobial activity
}

\author{
Ling Yun Zhong ${ }^{1,2}$, Liang Zou ${ }^{1}$, Xiao Hui Tang ${ }^{1}$, Wen Fei $\mathrm{Li}^{1}$, Xing $\mathrm{Li}^{1}$, Gang \\ Zhao ${ }^{1}$ and Jiang Lin Zhao ${ }^{1 \star}$ \\ ${ }^{1}$ Key R\&D Laboratory for Coarse Cereals, Chengdu University, Chengdu 610106, ${ }^{2}$ Department of Biological Sciences, College \\ of Life Sciences, Sichuan University, Chengdu 610065, Sichuan, China
}

${ }^{*}$ For correspondence: Email: jlzhao@cdu.edu.cn; Tel: +862884616653

Received: 26 September 2016

Revised accepted: 12 January 2017

\begin{abstract}
Purpose: To isolate and identify the fungal endophytes of Fagopyrum tataricum and assess their antimicrobial activity.

Methods: The fungal isolates were identified according to their morphological characters and internal transcribed spacer (ITS) sequence analysis. Both broth-dilution-colorimetric assay and spore germination test were employed to assess the antimicrobial activity of fungal mycelia extracts..

Results: A total of 72 endophytic fungal isolates were successfully obtained from the healthy tissues of $F$. tataricum. On the basis of their morphological and molecular characteristics, thirteen distinct fungal isolates were identified, and belonged to Alternaria, Bionectria, Botryosphaeria, Fusarium, Guignardia, Nectria, Neonectria, Phomopsis, Pseudocercospora and Verticillium spp. Of these, Pseudocercospora owned the maximum colonization frequency (15.3\%), next for Alternaria (12.5\%) and Neonectria (11.1 $\%)$. Through antimicrobial screening assays, six endophytes (Fataf-4, 6, 9, 11, 12 and 15) were active against Bacillus subtilis, Staphylococcus aureus, Agrobacterium tumefaciens, Escherichia coli and Pseudomonas lachrymans, and their minimal inhibitory concentration (MIC) ranged from 0.125 to 2.00 $\mathrm{mg} / \mathrm{mL}$. Furthermore, the endophytes, Fataf-9 and Fataf-11, also displayed strong inhibitory activity on the spore germination of $F$. oxysporum $f$. sp. vasinfectum and F. oxysporum $f$. sp. cucumerinum, and their median effective inhibitory concentration $\left(I_{50}\right)$ was $0.356,0.463,0.451$ and $0.489 \mathrm{mg} / \mathrm{mL}$, respectively.

Conclusion: The endophytic fungi of $F$. tataricum appear to be diverse and promising in their antimicrobial activity, and may represent a potential source of antibiotics for agriculture and/or pharmaceutical applications.
\end{abstract}

Keywords: Endophytic fungi, Fagopyrum tataricum, Diversity, Antimicrobial activity, Antibiotics, Pseudocercospora

Tropical Journal of Pharmaceutical Research is indexed by Science Citation Index (SciSearch), Scopus, International Pharmaceutical Abstract, Chemical Abstracts, Embase, Index Copernicus, EBSCO, African Index Medicus, JournalSeek, Journal Citation Reports/Science Edition, Directory of Open Access Journals (DOAJ), African Journal Online, Bioline International, Open-J-Gate and Pharmacy Abstracts

\section{INTRODUCTION}

Currently, there is an on-going search for novel antimicrobials which are expected to be high efficiency, low toxicity, eco-friendly and easily obtainable as the number of drug-resistant pathogens continues to increase [1,2]. Microorganisms, in particular endophytic fungi, have been recognized as outstanding reservoir of novel bioactive metabolites with pronounced antibacterial, antifungal and antiviral activities, exhibiting great potential applications in 
agriculture, pharmaceutical and the food industry $[3,4]$. During the past two decades, many new and valuable functional components such as alkaloids, terpenoids, steroids, quinines, lignans, phenols and lactones have been discovered from fungal endophytes [5,6]. A comprehensive investigation indicated that nearly $50 \%$ of the active compounds originated from fungal endophytes were previously unknown, and most of them exhibited strong antimicrobial activity [7].

Fagopyrum tataricum (Polygonaceae), also named tartary buckwheat, is a famous medicinal and edible coarse cereal, mainly cultivated in the highland and alpine areas of southwest of China, northern India, Bhutan and Nepal etc [8]. It is rich in proteins, unsaturated fatty acid, amino acids, vitamins and trace elements, as well as various functional phytochemicals, and has been widely used as a daily diet and traditional medicine and has a long history of medicinal uses [9]. The main bioactive constituents of tartary buckwheat are confirmed to be flavonoids (i.e. rutin, quercetin, and kaempferol), phenolics, D-chiroinositol, emodin and fagopyrins, with notable antimicrobial, antioxidant, antitumor, hypocholesterolemic, and antidiabetic activities $[10,11]$.

Currently, very little is known about the fungal endophytes residing in tartary buckwheat, as the community composition and diversity of endophytic fungi associated with $F$. tartaricum have never been reported.

To provide foundational information for further exploration and utilization of these valuable microorganisms, the aim of present study was to isolate and characterize the endophytic fungal isolates of $F$. tataricum, and to determine their frequencies of colonization. Moreover, their potency for the production of antimicrobial components was evaluated further.

\section{EXPERIMENTAL}

\section{Host plant collection}

The healthy stems of $F$. tataricum were collected in the Jintang county of Chengdu, Sichuan province of China in June 2012, labeled and preserved in sealed plastic bags in a portable fridge. The samples were then brought to the Coarse Cereal Research \& Development Center (CCRDC) at Chengdu University, and processed within $24 \mathrm{~h}$ of collection. Professor Gang Zhao of Chengdu University authenticated the taxonomic identity of the plant material.

\section{Isolation of the fungal endophytes}

The isolation of fungal endophytes was carried out according to the method by Zhong et al [12]. Firstly, the healthy tissues of $F$. tataricum were washed in running water for 2 min, followed by surface sterilization in $75 \%$ ethanol for $2 \mathrm{~min}, 0.2$ $\%$ mercuric chloride for $5 \mathrm{~min}$, and then rinsed in distilled water for three times $(1 \mathrm{~min}$ for each time), and then by drying on autoclaved filter papers. The sterilization efficacy was verified by inoculation of the last washing water onto $9 \mathrm{~cm}$ diameter Petri dishes including potato dextrose agar (PDA) medium. After surface sterilization, the samples were cut into small segments (approx. $5 \times 5 \mathrm{~mm}$ ), and placed on PDA medium supplemented with $200 \mu \mathrm{g} / \mathrm{mL}$ of streptomycin sulfate for inhibiting the growth of bacteria. All plates were incubated in the dark at $25^{\circ} \mathrm{C}$ for 30 days and checked everyday. When fungal colonies developed, they were transferred onto fresh PDA plates. Then, the fungal endophytes were isolated and sub-cultured to get a pure culture for further identification. The colonization frequency (CF \%) of each endophyte was determined by the method of Hata and Futai [13]. CF $=\left(N_{C O L} / N_{t}\right) \times 100$, where $N_{C O L}$ is the number of segments colonized by each fungus, and $N_{t}$ is the total number of segments.

\section{Identification of the fungal endophytes}

The endophytic fungal isolates were identified based on their morphological characteristics and internal transcribed spacer (ITS) rRNA gene sequence analysis. The morphological characters were made mainly depending on their macroscopic traits of the colonies (color, colony diameter, aspect and presence of pigmentation) and microscopic features (morphology of hyphae and conidia). Standard taxonomic references were employed to identify the fungal genera and species [14]. Through dereplication, sixteen representative fungal isolates with their different morphological characters were selected for further molecular identification. For the genomic DNA extraction, about 50-100 mg fresh mycelia of each fungal isolate were harvested from the surface of the PDA. The genomic DNA of each endophyte was extracted utilizing the SK1375 fungal genomic DNA extraction kits (Sangon Biotech, Shanghai, China). The polymerase chain reaction (PCR) for sequencing was performed in a BBT (Canada) with primers ITS1 (5'-TCCGTAGGTGAACCTGCGG-3') and ITS4 (5'-TCCTCCGCTTATTGATATGC-3').

Amplification was proceeded in a $25 \mu \mathrm{L}$ reaction mixture including $1 \mu \mathrm{L}$ genomic DNA, $10 \mu \mathrm{M}$ primer (each) $0.5 \mu \mathrm{L}, 10 \mathrm{mM}$ dNTP mix (each) 
$0.5 \mu \mathrm{L}, 10^{\star}$ Taq reaction buffer $2.5 \mu \mathrm{L}, 5 \mathrm{U} / \mu \mathrm{L}$ Taq DNA ploymerase $0.2 \mu \mathrm{L}$, and $d d \mathrm{H}_{2} \mathrm{O} 18.3$ $\mu \mathrm{L}$. The PCR procedure was set as follows, predenaturation at $94{ }^{\circ} \mathrm{C}$ for 5 min, subsequently 35 cycles of denaturation at $94{ }^{\circ} \mathrm{C}$ for $30 \mathrm{~s}$, annealing at $55{ }^{\circ} \mathrm{C}$ for $35 \mathrm{~s}$, extension at $72{ }^{\circ} \mathrm{C}$ for $1 \mathrm{~min}$, and extension at $72{ }^{\circ} \mathrm{C}$ for $8 \mathrm{~min}$ at last. The PCR product was further purified using the SK1131 gel extraction kits (Sangon Biotech, Shanghai, China), and sequenced by using the primer pair ITS1 and ITS4 on a ABI PRISM 3730 sequencer. After that, the sequences were edited by BLASTN program against the database (National Center for Biotechnology Information, NCBI), and submitted to GenBank to apply for the accession numbers. Phylogenetic analysis was carried out according to the ITS-rDNA gene data using neighbor joining $(\mathrm{NJ})$ approaches and the MEGA 5.0 software. NJ trees were constructed on the basis of the total character differences and bootstrap values calculated from 1,000 replications.

\section{Mycelia suspension culture and extract preparation}

After the fungal endophytes grown on PDA plates at $25^{\circ} \mathrm{C}$ in the dark for 5-7 days, two to three agar plugs with fungal mycelia were inoculated into a $500-\mathrm{mL}$ conical flask containing $200 \mathrm{~mL}$ liquid potato dextrose (PD) medium. All flasks were incubated at $150 \mathrm{rpm}$ on a rotary shaker at $25{ }^{\circ} \mathrm{C}$ in the dark for 14 days. Afterwards, the fungal cultures was filtrated under vacuum to obtain the mycelia. Then, the mycelia were lyophilized and powdered with a mortar and pestle, and extracted with methanol under sonication for three times. Finally, the methanol extractions were concentrated under vacuum at $35-40{ }^{\circ} \mathrm{C}$ until dryness to obtain the endophytic fungal mycelia extracts.

\section{Detection of antibacterial activity of the fungal extracts}

A modified micro-broth-dilution-colorimetric assay was applied to evaluate the antibacterial activity of the fungal mycelia extracts [15]. Five test microorganisms included two gram-positive (Bacillus subtilis ATCC 11562 and Staphylococcus aureus ATCC 6538), and three gram-negative (Agrobacterium tumefaciens ATCC 11158, Escherichia coli ATCC 29425, Pseudomonas lachrymans ATCC 11921) bacteria. They were grown in liquid Luria-Bertani (LB) medium (yeast extract $5.0 \mathrm{~g} / \mathrm{L}$, peptone 10.0 $\mathrm{g} / \mathrm{L}, \mathrm{NaCl} 5.0 \mathrm{~g} / \mathrm{L}, \mathrm{pH} 7.0$ ) for $24 \mathrm{~h}$ at $30 \stackrel{\circ}{\circ}$, and the concerntration of bacterial suspension was adjusted to $1 \times 10^{6} \mathrm{cfu} / \mathrm{mL}$ for detection. The mycelia extract was dissolved and diluted with 30
$\%$ methanol $(\mathrm{MeOH})$ to obtain concentrations in the range of 20.0 to $1.25 \mathrm{mg} / \mathrm{mL}$, respectively. Then test sample solutions $(10 \mu \mathrm{L})$ and prepared bacterial suspension $(90 \mu \mathrm{L})$ were added into each well of the 96-well microplate. Each well of the negative control $\left(\mathrm{CK}^{-}\right)$contained $90 \mu \mathrm{L}$ of the inoculum $\left(1 \times 10^{6} \mathrm{cfu} / \mathrm{mL}\right)$ and $10 \mu \mathrm{L}$ of $30 \%$ $\mathrm{MeOH}$. Streptomycin sulfate was served as the positive control $\left(\mathrm{CK}^{+}\right)$. All treatments were performed in triplicate. The 96-well microplates were agitated to mix the contents of the wells using a plate shaker, and incubated in the dark at $30{ }^{\circ} \mathrm{C}$ for $24 \mathrm{~h}$. Then, $10 \mu \mathrm{L}$ of $0.5 \mathrm{mg} / \mathrm{mL}$ of 3 (4,5-dimethylthiazol-2-yl)-2,5-diphenyltetrazolium bromide (MTT, dilluted in $0.2 \mathrm{~mol} / \mathrm{L}$ of phosphate buffered saline, PBS, pH 7.2) was added into each well, and the plates were incubated for another $30 \mathrm{~min}$. The minimum inhibitory concentration (MIC) value was defined as the lowest sample concentration that inhibited visible growth, as indicated by the MTT staining. Only living bacteria could convert MTT to formazan, and blue color appeared in the well [16].

\section{Assessment of antifungal activity of the fungal extracts}

Two phytopathogenic fungi Fusarium oxysporum f. sp. vasinfectum and Fusarium oxysporum f. sp. cucumerinum (kindly provided by Dr. Ligang Zhou, MOA Key Laboratory of Plant Pathology, College of Plant Protection, China Agricultural University) were selected as the test microorganisms. A spore germination test was used to investigate the antifungal activity of the mycelia extracts according to the method provided by Liu et al [17]. In brief, each test fungus was inoculated into PD medium for 4-7 days at $25^{\circ} \mathrm{C}$ in the dark. The fungal cultures were filtrated with sterile cloth to remove the mycelia, and the filtrate was centrifuged at 10000 rpm for $3 \mathrm{~min}$. The obtained spores were resuspended with sterilized water to get a spore suspension containing $1 \times 10^{6}$ spores $/ \mathrm{mL}$. The test sample solutions $(5 \mu \mathrm{L})$ and prepared fungal spore suspension $(45 \mu \mathrm{L})$ were mixed uniformly, and then added onto concave glass slides. The negative control was $3 \% \mathrm{MeOH}$, and the positive control was carbendazim with concentrations from 50.0 to $0.78 \mu \mathrm{g} / \mathrm{mL}$. After incubation in a moist chamber at $25^{\circ} \mathrm{C}$ for $7 \mathrm{~h}$, each slide was examined under the microscope for spore germination status. About 100 spores per replicate were checked and the spore germination status recorded. The inhibition rate of spores germination was calculated as $\left(\mathrm{G}_{c}-\right.$ $\mathrm{Gs} / \mathrm{G} c$, where $\mathrm{Gc}$ is an average of three replicates of germinated spore numbers in the negative control, and $G s$ is an average of three replicates of germinated spores in the test 
sample. The median effective inhibitory concentration $\left(\mathrm{IC}_{50}\right)$ was calculated using the linear relation between the inhibitory probability and concentration logarithm according to the method of Sakuma [18].

\section{Statistical analysis}

All treatments were carried out in three times, and the results were expressed as mean values and their standard deviations (SD)., The data were submitted to analysis of variance (one-way ANOVA) to determine significant differences by PROC ANOVA of SAS version 8.2. The term significant has been used to denote the differences for which $p \leq 0.05$.

\section{RESULTS}

\section{Isolation and identification of the endophytic fungal isolates of $\boldsymbol{F}$. tataricum}

A total of seventy-two fungal isolates were separated from the healthy tissues of Fagopyrum tataricum. These endophytic fungi were identified using a combination of morphological and molecular methods. According to their morphological traits, the seventy-two fungal isolates were preliminary grouped through dereplication into sixteen different morphological taxa, and these representative isolates were then selected for DNA sequence analysis using the ITS region. The ITS (ITS1-5.8S-ITS2) sequences of these endophytic fungi were compared to corresponding sequences of reference fungal taxa in the database. The results showed that thirteen fungal isolates were identical to the members of eleven different genera, including Alternaria, Bionectria, Botryosphaeria, Fusarium,
Guignardia, Nectria, Neonectria, Phomopsis, Plectosphaerella, Pseudocercospora and Verticillium (Table 1). Where there were no reproductive structures, isolates of Fataf-2 and Fataf-7 were only grouped into the Arthopyreniaceae, and Fataf-3 was primary classified to the Massarinaceae according to the results of their DNA sequence analysis, which need further identification in the future. The diversity of these fungi associated with the $F$. tataricum was revealed by colonization frequency (CF). Of them, the Pseudocercospora had the maximum colonization frequency of $15.3 \%$, followed by Alternaria with $12.5 \%$, Neonectria with $11.1 \%$, and Phomopsis with $8.3 \%$. Some of them had been reported to be found most often as fungal endophytes in various plant tissues $[12,19,20]$.

\section{Phylogenetic relationship analysis of the fungal endophytes of $\boldsymbol{F}$. tataricum}

The ITS sequence data of sixteen fungal endophytes from $F$ tataricum have been successfully submitted to the GenBank database under the accession numbers of KC218445 to KC218460 (Table 1). The sequence data of closet related species were obtained from the GenBank database. These dataset were used to construct the phylogenetic tree with neighborjoining method, and to analyze the phylogenetic affiliation of these endophytes. The 16 fungal isolates could be sorted to five groups,

Hypocreales (Group I), Diaporthales (Group II), Capnodiales (Group III), Botryosphaeriales (Group IV) and Pleosporales (Group V), all of which belonged to the Dothideomycetes and Sordariomycetes (Figure 1).

Table 1: Colonization frequency (CF) of the endophytic fungal isolates of $F$. tataricum and their closest relatives based on the data from BLAST analysis and morphological identification

\begin{tabular}{|c|c|c|c|c|c|}
\hline $\begin{array}{l}\text { Fungal } \\
\text { isolate }\end{array}$ & $\begin{array}{l}\text { CF } \\
(\%)\end{array}$ & $\begin{array}{c}\text { GenBank } \\
\text { accession } \\
\text { Number }\end{array}$ & Closest related species & $\begin{array}{c}\text { Similarity } \\
(\%)\end{array}$ & $\begin{array}{c}\text { Macro } \\
\text { and microscopic } \\
\text { identification }\end{array}$ \\
\hline Fataf-1 & $5.7(4 / 72)$ & KC218445 & Bionectria ochroleuca AB369487 & 99 & Bionectria sp. \\
\hline Fataf-2 & $1.4(1 / 72)$ & KC218446 & Uncultured Arthopyreniaceae GU327436 & 99 & Arthopyreniaceae \\
\hline Fataf-3 & $1.4(1 / 72)$ & KC218447 & Massarinaceae JF502440 & 98 & Massarinaceae \\
\hline Fataf-4 & $2.8(2 / 72)$ & KC218448 & Plectosphaerella cucumerina GU479908 & 99 & Plectosphaerella sp. \\
\hline Fataf-5 & $11.1(8 / 72)$ & KC218449 & Neonectria macrodidyma AM419068 & 99 & Neonectria sp. \\
\hline Fataf-6 & $4.2(3 / 72)$ & KC218450 & Bionectria pityrodes AY254158 & 99 & Bionectria sp. \\
\hline Fataf-7 & $2.8(2 / 72)$ & KC218451 & Arthopyreniaceae sp. DQ682563 & 99 & Arthopyreniaceae \\
\hline Fataf-8 & $2.8(2 / 72)$ & KC218452 & Nectria haematococca GU066713 & 100 & Nectria sp. \\
\hline Fataf-9 & $9.7(7 / 72)$ & KC218453 & Fusarium oxysporum EU285554 & 100 & Fusarium sp. \\
\hline Fataf-10 & $5.6(4 / 72)$ & KC218454 & Guignardia mangiferae JN791606 & 99 & Guignardia sp. \\
\hline Fataf-11 & $15.3(11 / 72)$ & KC218455 & Pseudocercospora elaeodendri GU980950 & 99 & Pseudocercospora sp. \\
\hline Fataf-12 & $6.9(5 / 72)$ & KC218456 & Botryosphaeria sp. HQ731645 & 99 & Botryosphaeria sp. \\
\hline Fataf-13 & $8.3(6 / 72)$ & KC218457 & Phomopsis sp. AB302247 & 99 & Phomopsis sp. \\
\hline Fataf-14 & $6.9(5 / 72)$ & KC218458 & Alternaria mali AB470849 & 100 & Alternaria sp. \\
\hline Fataf-15 & $5.6(4 / 72)$ & KC218459 & Alternaria sp.HE608798 & 99 & Alternaria sp. \\
\hline Fataf-16 & $4.2(3 / 72)$ & KC218460 & Verticillium dahliae HQ839784 & 100 & Verticillium sp. \\
\hline
\end{tabular}


Group I was made up of endophytes Fataf-1, Fataf-4, Fataf-5, Fataf-6, Fataf-8, Fataf-9 and Fataf-16. In this group, Fataf-1 and Fataf- 6 were claded with Bionectria spp. accessions. The endophyte Fataf-1 was found to be $99 \%$ identical to Bionectria ochroleuca (AB369487, $100 \%$ coverage) and Bionectria sp. (FJ23188, $100 \%$ coverage). Fataf-6 was $99 \%$ identical to Bionectria pityrodes (AY254158, $96 \%$ coverage), and formed a supporting clade. The fungal isolate Fataf-4 was most likely Plectosphaerella cucumerina, with $99 \%$ similarity to both GU479908 (100\% coverage) and EU326201 (100\% coverage) in the BLAST search. Fataf-16 was $100 \%$ identical to Verticillium dahliae HQ839784 (100\% coverage) and $99 \%$ with Verticillium sp. (HQ829127, $97 \%$ coverage), and they formed a clade with $100 \%$ bootstrap supports. For the endophyte Fataf-5, it had $99 \%$ similarity both to Neonectria macrodidyma AM419068 (100\% coverage) and Neonectria sp. HQ731630 (100\% coverage), and the bootstrap value (100\%) supported this grouping. Fataf-8 and Fataf-9 showed $100 \%$ similarity with Nectria haematococca AY310442 (100\% coverage) and Fusarium oxysporum EU285554 (100 \% coverage) respectively.

The Group II included fungal isolate Fataf-13, which showed $99 \%$ identical to Phomopsis sp. (AB302247 and AF102999). The endophyte Fataf-13, and Phomopsis spp. (AB302247 and AF102999) formed a well-supported clade with a $100 \%$ bootstrap value. The endophytic fungus Fataf-11 was in the group of Capnodiales (Group III), and it was $99 \%$ identical to Pseudocercospora elaeodendri GU980950 (100\% coverage). The Group IV contained endophytes Fataf-10 and Fataf-12. Endophyte Fataf-10 was in a clade with Guignardia sp., and showed $99 \%$ similarity to $G$. mangiferae JN791606 in a BLAST search. Fataf-12 and Botryosphaeria sp. HQ731645 formed a clade with $97 \%$ bootstrap value, and their similarity was as much as $99 \%$. The last group (Group V) was composed of five fungal endophytes (Fataf2, Fataf-3, Fataf-7, Fataf-14 and Fataf-15). Fataf2 and Fataf-7 were in a clade, and identical to Arthopyreniaceae sp. DQ682563 with $99 \%$ similarity. The fungal endophyte Fataf-3 was $98 \%$ identical to Massarinaceae sp. JF502440 (98\% coverage). Fataf-14 and Fataf-15 exhibited 99 - $100 \%$ similarity to Alternaria spp. HE608798 and Alternaria mali AB470849 respectively, and they formed well clade with other Alternaria spp. (AY904063, HQ731643), with $100 \%$ bootstrap value.

\section{Antibacterial activity of the endophytic fungal extracts}

The antibacterial activity of sixteen endophytic fungal mycelia extracts was evaluated against five test bacteria, including two phytopathgenic bacteria ( $A$. tumefaciens and $P$. lachrymans), two clinical bacteria ( $E$. coli and $S$. aureus) and one Bacillus subtilis. As displayed in Table 2, the mycelia extracts of endophytic fungi Fataf-9 (Fusarium sp.) and Fataf-11 (Pseudocercospora sp.) were more active than other endophytes against all the test bacteria, with their MIC values ranged from 0.125 to $1.50 \mathrm{mg} / \mathrm{mL}$. A few mycelia extracts (i.e. Fataf-4, Fataf-6, Fataf-12 and Fataf15) also exhibited inhibitory activity on the test bacteria, with their MIC values ranged from 0.50 to $2.00 \mathrm{mg} / \mathrm{mL}$. Although, the mycelia extracts of three endophytes (Fataf-4, Fataf-7 and Fataf-14) did not show any antibacterial activity at the maximal concentration of $2.00 \mathrm{mg} / \mathrm{mL}$ in the broth dilution test, and their MIC values should be greater than $2.00 \mathrm{mg} / \mathrm{mL}$. In general, the gram-negative bacteria were more sensitive to the mycelia extracts than the gram-positive bacteria in this investigation.

\section{Antifungal activity of endophytic fungal extracts}

According to our preliminary investigation, the crude mycelia extracts of endophytes Fataf-9 and Fataf-11 exhibited high inhibitory activity on the spore germination of two test phytopathogens ( $F$. oxysporum f. sp. vasinfectum and $F$. oxysporum f. sp. cucumerinum), and the spores germination rates were lower than $5.0 \%$ at a concentration of $2.00 \mathrm{mg} / \mathrm{mL}$. However, the mycelia extracts of other 14 fungal isolates exhibited weak or no inhibitory activities on the test fungi, and their spore germination rates were all above $60.0 \%$ at the maximal concentration of $2.00 \mathrm{mg} / \mathrm{mL}$ (data not shown). Hence, the endophytes Fataf-9 and Fataf-11 were selected as the two promising candidates for further investigation. As shown in Figure 2A, the endophyte Fataf-9 and Fataf-11 exhibited strong inhibitory activity on the spore germination of $F$. oxysporum f. sp. vasinfectum, and the inhibitory effects was concentration-dependent. With the treatment of mycelia extracts $(200-1000 \mu \mathrm{g} / \mathrm{mL})$ of endophyte Fataf-9 and Fataf-11, the spores germination of $F$. oxysporum f. sp. vasinfectum was notably inhibited, and the inhibition percentage was from 18.75 to $95.75 \%$. Correspondingly, their $\mathrm{IC}_{50}$ value was determined to be $0.356 \mathrm{mg} / \mathrm{mL}$ and $0.463 \mathrm{mg} / \mathrm{mL}$, respectively (Table 3 ). For the spore germination of $F$. oxysporum f. sp. cucumerinum, it was also significantly inhibited by the endophytes Fataf- 9 
and Fataf-11 (Figure 2B). After treatment with the mycelia extracts of Fataf-9 and Fataf-11 (1000 $\mu \mathrm{g} / \mathrm{mL}$ ), most of the fungal spores was inhibited or declined, and their inhibition ratio was as much as 91.00 and $89.25 \%$, respectively.
Moreover, the $\mathrm{IC}_{50}$ value of endophyte Fataf-9 and Fataf-11 against $F$. oxysporum f. sp. cucumerinum was measured as $0.451 \mathrm{mg} / \mathrm{mL}$ and $0.489 \mathrm{mg} / \mathrm{mL}$ (Table 3).

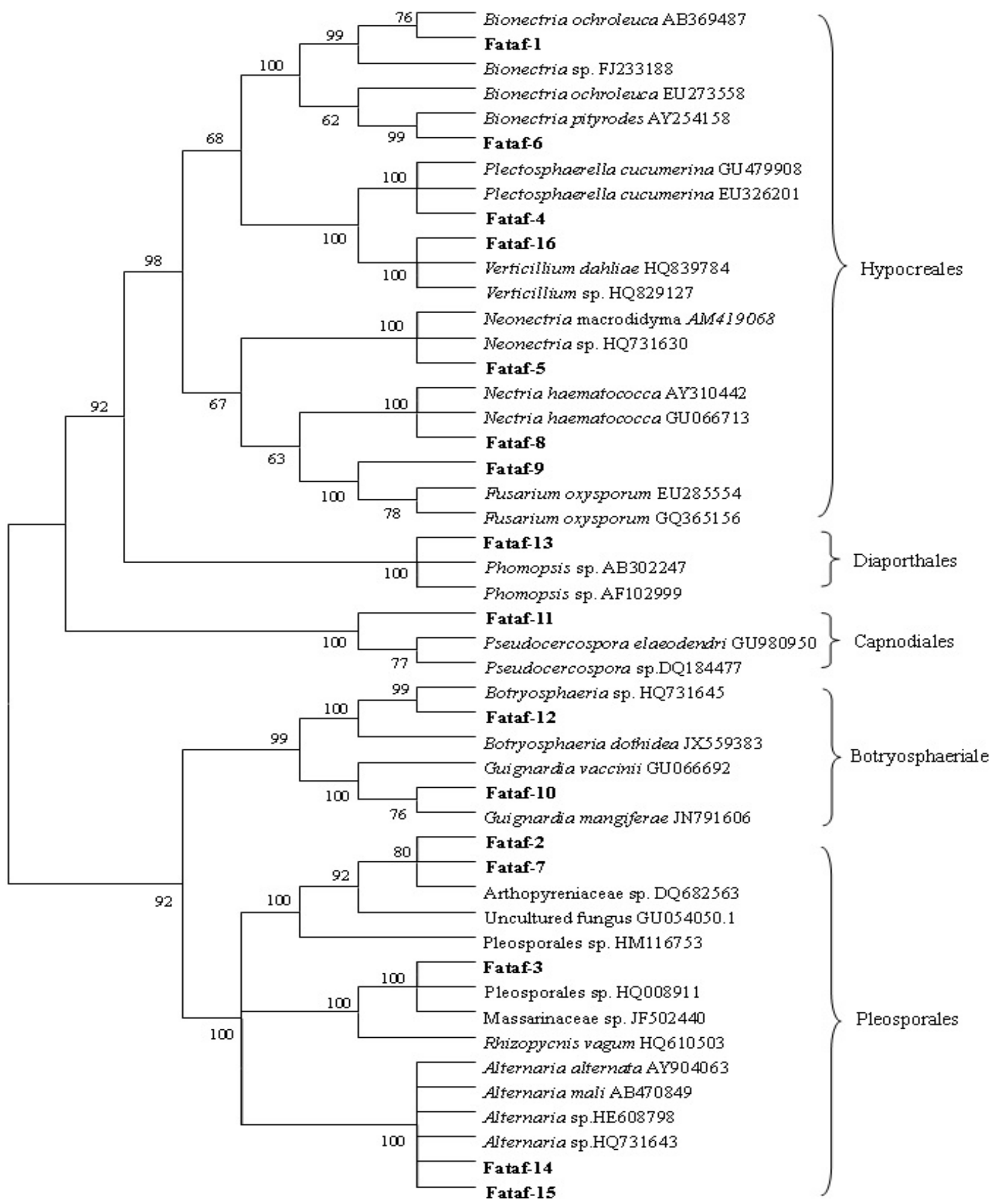

Figure 1: Phylogenetic relationship analysis of the endophytic fungal isolates from Fagopyrum tataricum. Phylogeny test are computed by MEGA 5.0. Bootstrap values (above $50 \%$ ) from 1000 replicates are indicated at each node 
Table 2: Antibacterial activity of sixteen fungal endophytes from $F$. tataricum against five test bacteria by broth dilution-MTT assay

\begin{tabular}{|c|c|c|c|c|c|}
\hline \multirow{2}{*}{$\begin{array}{l}\text { Fungal } \\
\text { isolate }\end{array}$} & \multicolumn{5}{|c|}{ Minimal inhibited concentration (MIC, $\mathrm{mg} / \mathrm{mL}$ ) } \\
\hline & B. subtilis & S. aureus & A. tumefaciens & E. coli & P. lachrymans \\
\hline Fataf-1 & * & - & 1.00 & 1.50 & 2.00 \\
\hline Fataf-2 & * & * & 2.00 & 2.00 & * \\
\hline Fataf-3 & - & - & $*$ & 2.00 & * \\
\hline Fataf-4 & 1.50 & 2.00 & 1.50 & 1.50 & 1.00 \\
\hline Fataf-5 & - & - & - & - & - \\
\hline Fataf-6 & 2.00 & 2.00 & 1.00 & 1.50 & 1.50 \\
\hline Fataf-7 & - & - & - & - & - \\
\hline Fataf-8 & * & - & 2.00 & 2.00 & * \\
\hline Fataf-9 & 0.50 & 1.00 & 0.125 & 0.125 & 0.25 \\
\hline Fataf-10 & -- & -- & -- & 3.0 & -- \\
\hline Fataf-11 & 1.00 & 1.50 & 0.50 & 0.50 & 0.25 \\
\hline Fataf-12 & 2.00 & * & 0.50 & 1.00 & 1.50 \\
\hline Fataf-13 & - & - & 2.00 & $*$ & * \\
\hline Fataf-14 & - & - & - & - & - \\
\hline Fataf-15 & 2.00 & 2.00 & 1.50 & 1.00 & 1.50 \\
\hline Fataf-16 & * & * & 1.50 & 2.00 & 2.00 \\
\hline $\mathrm{CK}^{-}$ & - & - & - & - & - \\
\hline $\mathrm{CK}^{+}$ & 0.10 & 0.20 & 0.08 & 0.06 & 0.06 \\
\hline
\end{tabular}

Data in the table are MIC values ( $\mathrm{mg} / \mathrm{mL}$ ) of the fungal extracts against test bacteria. *, antibacterial activity was not detected at $2.00 \mathrm{mg} / \mathrm{mL}$ for the extract. -, no inhibition. CK, $3 \%$ Methanol, $\mathrm{CK}^{+}$, streptomycin sulfate
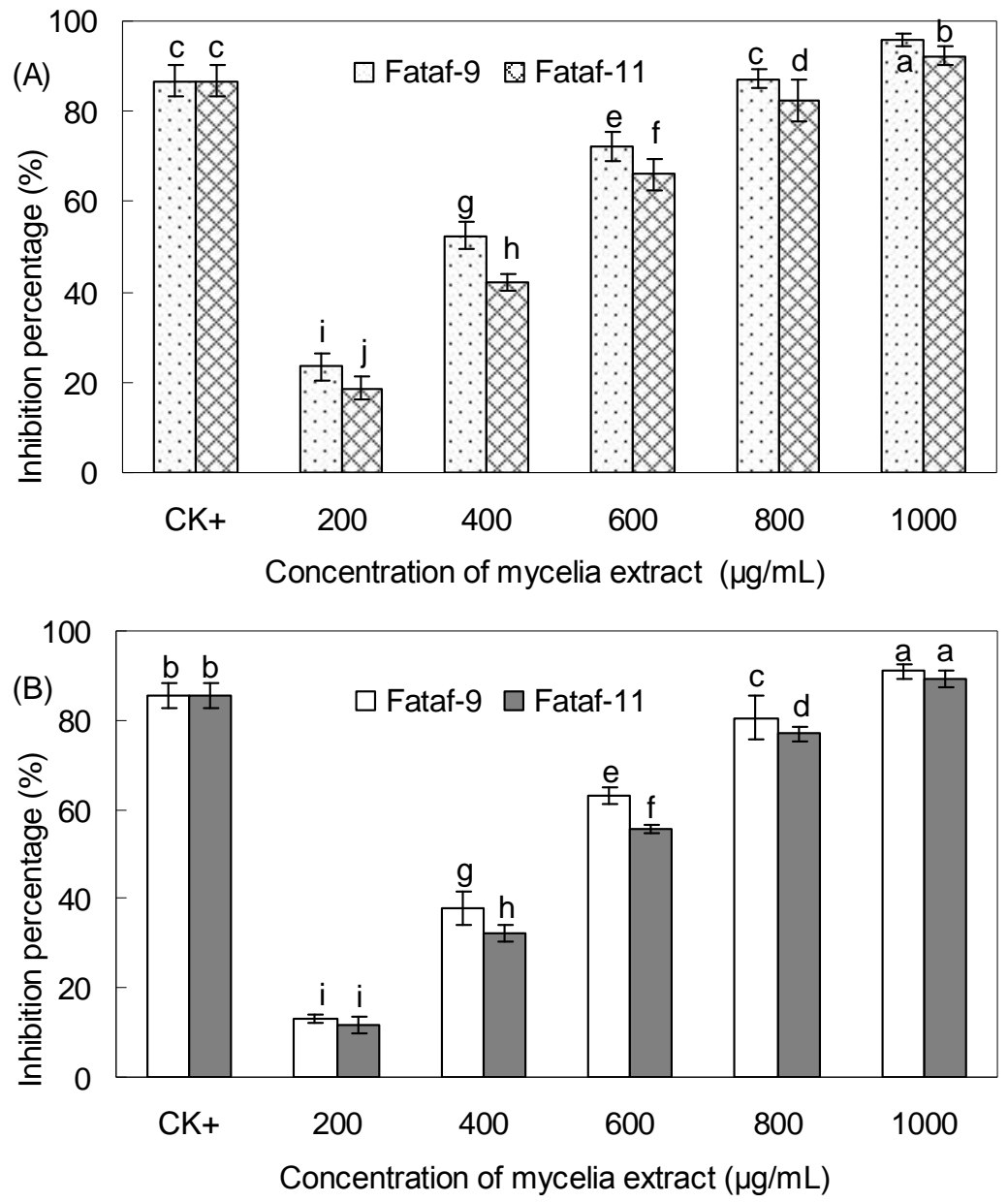

Figure 2: The inhibitory activities of endophytes Fataf-9 and Fataf-11 on spore germination of Fusarium oxysporum f. sp. vasinfectum (A) and F. oxysporum f. sp. cucumerinum (B), $\mathrm{CK}^{+}$, carbendazim $(0.05 \mathrm{mg} / \mathrm{mL})$. Different letters (i.e., a-j) indicate significant differences among the treatments $(p=0.05)$ 
Table 3: Antifungal activity of endophytes Fataf- 9 and Fataf-11 on the spore germination of Fusarium oxysporum f. sp. vasinfectum and $F$. oxysporum $\mathrm{f}$. sp. cucumerinum

\begin{tabular}{|c|c|c|}
\hline \multirow{2}{*}{ Fungal isolate } & \multicolumn{2}{|c|}{ Median effective inhibitory concentration $\left(\mathrm{IC}_{50}, \mathrm{mg} / \mathrm{mL}\right)$} \\
\hline & F. oxysporum f. sp.vasinfectum & F. oxysporum f. sp. vasinfectum \\
\hline Fataf-9 & 0.356 & 0.451 \\
\hline Fataf-11 & 0.463 & 0.489 \\
\hline $\mathrm{CK}^{-}$ & - & - \\
\hline $\mathrm{CK}^{+}$ & 0.035 & 0.028 \\
\hline
\end{tabular}

Generally, both endophyte Fataf-9 and Fataf-11 were determined to have strong antifungal activity against the two test phytopathogens, and the extract of endophyte Fataf-9 (Fusarium sp.) was more active than that of endophyte Fataf-11 (Pseudocercospora elaeodendri). The Fusarium $\mathrm{sp}$. has been found more often as fungal endophytes in various plants, and they could produce many valuable antimicrobial compounds such as cerebroside, fusaruside and ergosta7,22-dien-3 $\beta, 5 \alpha, 6 \beta, 7 \alpha$-tetraol [21,22].

\section{DISCUSSION}

Plant endophytic fungi are defined as the beneficial fungal microorganisms which spend the whole or part of their lifecycle colonizing inside the healthy tissues of their host plants, usually causing no apparent symptoms of disease $[1,3]$. They are important components of plant micro-ecosystems. During the long period of co-evolution, fungal endophytes form a symbiotic relationship with their host plants. The host can provide plenteous nutriment and easeful habitation for the survival of its endophytes. In return, the fungal endophytes could produce many functional secondary metabolites for helping the host plant to resist external biotic and abiotic stresses (i.e. insects-pests, pathogens and domestic herbivores), and benefiting for the host growth $[3,4]$. So far, a large number of fungal endophytes have been obtained from economically important plants. Some of them have been screened to be capable of producing antimicrobial constituents. For example, Gond et al reported that 19 endophytic fungal isolates were isolated from the healthy tissues of Nyctanthes arbortristis, and 12 endophytic fungal extracts exhibited strong antibacterial activity against either one or more pathogenic bacteria [23]. The endophytes Colletotrichum dematium (NAT152) and Chaetomium globosum (NAT160) displayed a broad range of antibacterial activity and were active against Salmonella enteritidis, Salmonella paratyphi, Shigella boydii, Shigella flexneri, and Pseudomonas aeruginosa. Two endophytes (DS1 and BS1) were isolated from the leaves and stem of Piper crocatum, and the ethyl acetate extracts of BS1 was found to inhibit the growth of $B$. subtilis, E. coli and $S$. aureus at minimum doses of 31.25, 125 and $250 \mu \mathrm{g}$ [24]. One hundred and fifty six fungal isolates distributed across 19 taxa were separated from Calotropis procera, and six fungal endophytes were screened to show good antimicrobial activity against human pathogenic microorganisms and one plant pathogenic fungus [25].

\section{CONCLUSION}

To the best of our knowledge, this is the first report on the community of endophytic fungi from the medicinal and edible plant Fagopyrum tataricum and their antimicrobial activities. A total of seventy-two fungal isolates were successfully obtained from the healthy tissues of $F$. tataricum and successfully identified to genus or family level according to their morphological characters and molecular characteristics. Of them, the four most frequent genera were Pseudocercospora, Alternaria, Neonectria and Phomopsis. The mycelia extracts of endophyte Fataf-9 (Fusarium sp.) and Fataf-11 (Pseudocercospora sp.) appeared to be most promising, and may represent a potential source of antibiotics for agricultural or pharmaceutical applications. Further studies should focus on the fractionation, purification and identification of the antimicrobial metabolites from the two potential fungal endophytes.

\section{DECLARATIONS}

\section{Acknowledgement}

This work was co-financed by grants from Research Program of Sichuan Science and Technology Department (no. 2014JY0016), Special Fund for Agro-scientific Research in the Public Interest (no. 201303069-08), and Natural Science Foundation of Chengdu University (no. 2013XJZ09).

\section{Conflict of Interest}

No conflict of interest associated with this work. 


\section{Contribution of Authors}

The authors declare that this work was done by the authors named in this article and all liabilities pertaining to claims relating to the content of this article will be borne by them.

\section{Open Access}

This is an Open Access article that uses a funding model which does not charge readers or their institutions for access and distributed under the terms of the Creative Commons Attribution License (http://creativecommons.org/licenses/by 14.0) and the Budapest Open Access Initiative (http://www.budapestopenaccessinitiative.org/rea d), which permit unrestricted use, distribution, and reproduction in any medium, provided the original work is properly credited.

\section{REFERENCES}

1. Rodriguez RJ, White JF, Amold AE, Redman RS. Fungal endophytes: Diversity and functional roles. New Phytol 2009; 182: 314-340.

2. Deshmukh R, Mathew A, Purohit HJ. Characterization of antibacterial activity of bikaverin from Fusarium sp. HKF15. J Biosci Bioeng 2014; 117: 443-448.

3. Zhao J, Shan T, Mou Y, Zhou L. Plant-derived bioactive compounds produced by endophytic fungi. Mini-Rev Med Chem 2011;11: 159-168.

4. Alvin A, Miller KI, Neilan BA. Exploring the potential of endophytes from medicinal plants as sources of antimycobacterial compounds. Microbiol Res 2014; 169: 483-495.

5. Zhou L, Zhao J, Shan $T$, Cai $X$, Peng $Y$. Spirobisnaphthalenes from fungi and their biological activities. Mini-Rev Med Chem 2010; 10: 977-89.

6. Wang Y, Yang MH, Wang XB, Li TX, Kong LY. Bioactive metabolites from the endophytic fungus Alternaria alternate. Fitoterapia 2014; 99: 153-158.

7. Schulz B, Boyle C, Draeger S, Rommert AK, Krohn K. Endophyte fungi: a source of novle biologically active secondary metabolites. Mycol Res 2002; 106: 996-1004.

8. Fabjan N, Rode J, Košir IJ, Wang ZH, Zhang Z, Kreft I. Tartary buckwheat (Fagopyrum tataricum Gaertn.) as a source of dietary rutin and quercitrin. I Agric Food Chem 2003; 51: 6452-6455.

9. Zhao G, Zou L, Wang Z, Hu H, Hu Y, Peng L. Pharmacokinetic profile of total quercetin after single oral dose of tartary buckwheat extracts in rats. J Agric Food Chem 2011; 59: 4435-4441.

10. Qin $P Y$, Wu L, Yao $Y$, Ren GX. Changes in phytochemical compositions, antioxidant and $\alpha$ glucosidase inhibitory activities during the processing of tartary buckwheat tea. Food Res Int 2013; 50: 562-567.

11. Inglett, GE, Chen DJ, Berhow M, Lee S. Antioxidant activity of commercial buckwheat flours and their free and bound phenolic compositions. Food Chem 2011; 125: 923-929.

12. Zhong L, Zhou Y, Gao S, Xu L, Zhao J, Shan T, He W, Zhou L. Endophytic fungi from the hybrid 'Neva' of Populus deltoides Marsh $\times$ Populus nigra $L$. and their antimicrobial activity. Afr J Microbiol Res 2011; 5: 39243929.

13. Hata K, Futai $K$. Endophytic fungi associated healthy pine needles infested by the pine needle gall midge, Thecodiplosis japonensis. Can J Bot 1995; 73: 384-390.

14. Ainsworth GC, Sparrow FK, Sussman AS. The fungi, an advanced treatise, Edition Vol IV(A), a taxonomic review with keys ascomycetes and fungi imperfecti. Academic Press, New York, 1973.

15. Xu L, Zhou L, Zhao J, Li J, Li X, Wang J. Fungal endophytes from Dioscorea zingiberensis rhizomes and their antibacterial activity. Lett Appl Microbiol 2008; 46: 68-72.

16. Abe K, Matsuki N. Measurement of cellular 3-(4,5dimethylthizaol-2-yl)-2,5-diphenyl tetrazolium bromide (MTT) reduction activity and lactate dehydrogenase release using MTT. Neurosci Res 2000; 38: 325-329.

17. Liu H, Wang J, Zhao J, Lu S, Wang J, Jiang W, Ma Z, Zhou L. Isoquinoline alkaloids from Macleaya cordata active against plant microbial pathogens. Nat Prod Commun 2009; 4: 1557-1560.

18. Sakuma M. Probit analysis of preference data. Appl Entomol Zool 1998; 33: 339-347.

19. Verma VC, Gond SK, Kumar A, Kharwar RN, Strobel G. The endophytic mycoflora of bark, leaf, and stem tissues of Azadirachta indica A. Juss (Neem) from Varanasi (India). Microb Ecol 2007; 54: 119-125.

20. Carvalho CR, Gonçalves VN, Pereira CB, Johann $S$, Galliza IV, Alves TMA, Rabello A, Sobral MEG, Zani CL, Rosa CA, Rosa RLH. The diversity, antimicrobial and anticancer activity of endophytic fungi associated with the medicinal plant Stryphnodendron adstringens (Mart.) Coville (Fabaceae) from Brazilian savannah. Symbiosis 2012; 57: 95-107.

21. Shu RG, Wang FW, Yang YM, Liu YX, Tan RX. Antibacterial and xanthine oxidase inhibitory cerebrosides from Fusarium sp. IFB-121, an endophytic fungus in Quercus variabilis. Lipids 2004; 39: 667-673.

22. Huang $Y$, Zhao J, Zhou L, Wang M, Wang J, Li X, Chen $Q$. Antimicrobial compounds from the endophytic fungus Fusarium sp. Ppf4 isolated from the medicinal plant Paris polyphylla var. yunnanensis. Nat Prod Commun 2009; 4: 1455-1458.

23. Gond SK, Mishra A, Sharma VK, Verma SK, Kumar J, Kharwar RN, Kumar A. Diversity and antimicrobial activity of endophytic fungi isolated from Nyctanthes arbortristis, a well-known medicinal plant of India. Mycoscience 2012; 53: 113-121.

24. Astuti P, Wahyono, Nababan OA. Antimicrobial and cytotoxic activities of endophytic fungi isolated from Piper crocatum Ruiz \& Pav. Asian Pac J Trop Biomed 2014; 4: S592-596. 
25. Nascimento TL, Oki Y, Lima DMM, Almeida-Cortez JS, Fernandes GW, Souza-Motta CM. Biodiversity of endopytic fungi in different leaf ages of Calotropis procera and their antimicrobial activity. Fungal Ecol 2015; 14: 79-86. 